\title{
CONSOLIDATION OF ARGUMENTS IN FAVOR OF THE RIGHT OF ACCESS TO PUBLIC INFORMATION AS A FUNDAMENTAL RIGHT
}

\author{
MANUEL PALOMARES HERRERA ${ }^{1}$
}

\begin{abstract}
Analysis of the doctrinal position regarding the nature of the right of access to public information and the development of new arguments that reinforce and consolidate its fundamental nature. This right is recognized as a human right in many international declarations; in Spain the legislation of transparency and enforcement is deployed as an instrumental right although it is recognized by many states as an autonomous fundamental right without need to be linked to other fundamental rights.
\end{abstract}

Key words: Access to Public Information; Transparency; Fundamental Rights.

Summary: I. INTRODUCTION; II. CONSIDERATIONS AND POSTURES FROM THE SPANISH DOCTRINE; III. THE RECENT DEFENSE OF THE RIGHT OF ACCESS TO PUBLIC INFORMATION; IV. CONCLUSION.

\section{Abbreviations:}

AEPD: Agencia Española de Protección de Datos/ Spanish Agency for Data Protection.

Art.: Artículo/ Article.

BOE: Boletín Oficial del Estado/ Official State Gazette.

CE: Constitución Española/ Spanish Constitution.

CTBG: Consejo de la Transparencia y Buen Gobierno/ Transparency and Good Governance Council.

ID: Identidad/ Identity.

LOPD: Ley Orgánica de Protección de Datos/ Organic Law of Data Protection.

LTBG: Ley de Transparencia y Buen Gobierno/ Law of Transparency and Good Governance.

PRLT: Proyecto de Reglamento de la Ley de Transparencia/ Draft Regulation of the Transparency Law. PTBG: Portal de Transparencia y Buen Gobierno/ Portal of Transparency and Good Governance.

STC: Sentencia del Tribunal Constitucional/ Judgment of the Constitutional Court.

TIC: Tecnología de la Información y la Comunicación/ Information and Communication Technology.

\footnotetext{
${ }^{1}$ PhD Candidate in Law, Universidad de Jaén, Spain (mph00007@red.ujaen.es).
} 


\section{INTRODUCTION}

The Spanish constitutional model establishes fundamental rights (arts. 14 to 29) in the first section of the second chapter of Title I of the Constitution entitled "On Fundamental Rights and Public Liberties". The legal development of the matters that occupy those articles will be by a special procedure for the so called Organic Laws. This is established by art. 81.1 CE: "Organic laws are those relating to the development of fundamental rights and public freedoms, those which approve the Statutes of Autonomy and the general electoral system and other provisions in the Constitution".

Their guarantees are found in art. 53 CE [protection of ordinary courts, the Constitutional Court (161.1 CE)...]. In addition to the protection of fundamental rights by the Armed Forces and the State Security Corps and Forces, as well as the Public Prosecutor's Office ("Ministerio Fiscal"); it is also important to highlight the role of guarantor of the Spanish Ombudsman, according to art. $54 \mathrm{CE}$ "for the defense of rights included in this title, for which purpose supervise the activity of the Administration, giving an account to the Cortes Generales".

Many years have elapsed since the first legislative mention of the right of access to information in the Swedish Transparency Act of 1766. From this milestone, internationally accepted precepts have taken place, such as Article 14 of the Declaration of Rights of Man and Citizen of 1789, the seed of world declarations, Article 19 of the Universal Declaration of Human Rights of 1948 or Article 10 of the European Convention for the Protection of Human Rights and Fundamental Freedoms of 1950.

Although Spain possessed legislative elements guaranteeing partial access to information, it has never come to recognize it as a fundamental right. Law 19/2013 of December 9, of Transparency, Access to Public Information and Good Governance of Spain anchored this law in the constitutional law of art. 105. b) CE, an article referring to access to records and records instead of rights such as information, expression, participation in public affairs and other similar fundamental rights. This law has aroused movements in the doctrine where there are different positions that will be analyzed below.

\section{CONSIDERATIONS AND POSTURES FROM THE SPANISH DOCTRINE}

The doctrinal reasons that support the essential fundamentalism of the right of access from the first position to the present date attest to the constant evolutionary process that it has had, the interest aroused in the doctrine and the confrontation of positions. The constitutional reality and analyzed preconstitutionally by its norms show the static nature of the right of access, which continues in practice up to the present, and this would remain the dynamic if it were not for a nascent transverse opening movement.

The context of corruption and the irruption of transparency and free access as a counterweight in transversal areas such as the business, the digital media or the 
Administration gave way to a stage that claims the right of access as a fundamental right which I humbly included for consolidation and expansion purposes. Thus, we can say that there have been two differentiated stages with the before and after of the TICs and the LTBG as a turning point. A conservative stage that, without denying definitively fundamental right influences and making it administrative and therefore never comes to consider as such the right of access despite having it as a constitutional right relegated and that assists some fundamental rights. In this sense, RIDAO MARTÍN (2014: 7) considers that access to public information can no longer be limited by other fundamental rights or other constitutional rights or assets.

A new stage is forged with an "iusfundamentalist" sector (pro fundamental right of access) in the opposite position that absolutely models the right of access as a fundamental right by its relation of vital dependence with fundamental rights of arts. 14 to 19 CE. From the first drafts of a transparency bill, through the commissions of parliament in its drafting to the present day, this new doctrinal approach subordinates the right of access to the right to be informed mainly. The authors who recognize the right of access as linked to other fundamental rights such as the freedom of speech or expression and the right to take part in public affairs.

Apparently the aforementioned authors of the conservative stage did not have a doctrinal counterweight that allowed a fluid dichotomy during the 20th century because it was until now the doctrinal accepted line so that, these very numerous authors are representative of the assumption until the appearance of the sector pro fundamental right of access to public information influenced by comparative, contrasted, adapted and evolved reality.

In the first stage, experts as FERNÁNDEZ RODRIGUEZ, skeptic to add fundamental rights and acknowledged denialist ${ }^{2}$ or ÁLVAREZ RICO (1979: 111) as denialist of the fundamentalism of such a right and who links it without any mobility at the administrative law scale. The latter spoke of the right of access to administrative documents and not to public information in addition to relating this right to art. $20 \mathrm{CE}$ and $105 \mathrm{CE}$. Another doctrine of the same apparently negationist stage is that of POMED SÁNCHEZ (1989: 110), who does refer to the right to information frequently ["The constitutionalisation of the right of access to archives and administrative records presupposes, firstly, a specification for a specific functional scope of the right to information, which is generally contained inl art. 20.1.d) CE"] and even links it with the principle of transparency but does not speak of an autonomous human right nor of a fundamental access in public life although it links with art. 23.1 CE.

He starts from the idea of the interrelationship between the right to information, specifically in the field of public documentation, and the right to participation, according to which the author places the right of access to public information, not on

\footnotetext{
2 "I'm up to my hair and higher up. Everyone fills their mouths saying rights and nobody does what they have to do. Of fundamental rights, with which we have, spare. It seems to me, it is my opinion, that we have enough with what we have." Journal of meetings of the Constitutional Commission of the Congreso de los Diputados. No. 254. February 12, 2013, p. 43.
} 
the right to public information but on the right to participate in public affairs (POMED SÁNCHEZ, 1989: 96 and 160). Both authors are closely linked with fundamental rights without at any time cataloging the right of access as such, remaining in the instrumental sphere and conformist with the administrative role that it currently bears.

In addition to the instrumentalist links, there were in this stage autonomous criteria of denial, especially before 2000, such as those of EMBID IRUJO, who distanced any style of configuration as fundamental to the right of access to files, records or registers. According to this, its constitutional situation is the maximum criterion of interpretation, by which its inclusion in art. $105 \mathrm{CE}$ and not between arts. 14 to $29 \mathrm{CE}$ does not allow consider the right of access as a fundamental right in any case or by possible influence of international declarations. Currently, the theoretical and fundamentalist reasons for ratifying the defense of the EMBID IRUJO line are purely descriptive, without pointing out compelling reasons close to this position, such as that of ALEXY (1993: 63), who pointed to fundamentalism from this situation of rights commenting that "fundamental rights are those that belong only and exclusively to the very foundation of the State and are therefore recognized as such in the Constitution". This criterion of EMBID IRUJO seems a bit poor, conformist with the legal reality, leveraged in the immobility without opportunity for the constitutional evolution and far from the skepticism of that who tries to approach the legal reality to the social reality nevertheless and in spite of it, EMBID IRUJO (1994: 92) affirms that it is a subjective right legally configured that is possessed as long as one has the status of citizen admitting that there is a specific connection of this subjective right, with some fundamental rights such as those to free speech and to political participation of art. 20 and $23 \mathrm{CE}$, as their denialist counterparts say, because without access there would be no real possibilities of political participation.

As it is proper at this stage, EMBID IRUJO himself (1994: 94) argued that although the right of access has an exclusively legal configuration and it has not an essential content, this does not imply that its regulation should be only legal. He also added that the legislator can develop the causes that, according to the Constitution, except the constitutional principle and even can be considered "constitutional violation" the regulation that departs from art. $105 \mathrm{CE}$.

In addition to professional jurists, there are negationist positions within the legislature, such as that of the parliamentarian GOMEZ DE LA SERNA, who during the commission debate on the nature of the law doubted the defense that some experts like GUICHOT or SÁNCHEZ DE DIEGO had wielded in that the room for maneuver is marked by "a constitutional situation that we are given"3 and that would not give rise to any recognition other than the one that has the access in the art. 105. b) CE. OLABARRÍA MUÑOZ, attacked the defense of the right of access as a fundamental right of art. $20 \mathrm{CE}$ by stating that the defense by connection is "a somewhat imaginative or spiritualistic formula, that gives per saltum to article 20 of the Spanish Constitution

\footnotetext{
${ }^{3}$ Journal of Meetings of the Constitutional Commission of the Congreso de los Diputados. No. 254 of 12 February 2013, p. 32.
} 
the character or legitimation of the right to transparency of citizens when the jurisprudential sense of the Constitutional Court in relation with article 20 guarantees the information to the media, and that it has been linearly the jurisprudence with respect to this precept". ${ }^{4}$

On the other hand, with the turning point of the new millennium, another trend opens up, another stage in which a broad fundamentalist sector begins to be aligned ${ }^{5}$ in which several reformist authors are positioned influenced by the requirements of comparative law, by the new digital dimension of life. SÁNCHEZ DE DIEGO (2008: 41) refers to this important change in life and the contiguous change that must be experienced by the legal system, especially in fundamental rights when he says that the "configuration of a right that is within evolution continues to respond to the problems that arise as society develops". During the legislative process of the LTBG some of these authors were defending this issue. So, one of the doctrinal defenders is VILLORIA Y MENDIETA, who claimed in the sessions of the Constitutional Commission of the Congress that "First of all, as has often been said, it would have been ideal if the law were based on art. 20 of the Constitution and not on the art. 105.b) because somehow we would have constitutionalised as a fundamental right transparency" 6 .

It is striking the emerging iusfundamentalist fever since the administrative protection of the right of access in the LTBG, possibly because a change of course was expected and its aesthetic but static final result has driven to many researchers to take the step of the opposite critical motivation. This generalized movement makes us speak of an iusfundamentalist stage that reaches since the adoption of that law until now.

Thus, there are different types of doctrinal positions, both those that strongly value the right of access as fundamental and those that partially and succinctly consider it because of its link to other fundamental rights. CARBONELL is one of the first to differentiate himself from many other fundamentalists because he goes further and defends the constitutionalization of the right of access to information by itself and exclusively from the provisions of the Constitution as the basis of natural law, that being a response to the denialists who rely on the constitutional location of the right of access. This autonomous defense of the guarantee of essential goods and services must be reasoned, although controversial of course, since the right is not an exact science that determines what is or is not basic for each subject.

\footnotetext{
${ }^{4}$ Journal of Meetings of the Constitutional Commission of the Congreso de los Diputados. No. 254 of 12 February 2013, p. 41.

${ }^{5}$ Here we find, in addition to the constant elements of comparative law and authors that will be referred to below, authors whom we have alluded with assiduously as VILLANUEVA, E., RUIZ-RICO RUIZ, C., RIDAO MARTÍN, J., MENDEL, T., RAMS RAMOS, L., COTINO HUESO, L., SÁNCHEZ DE DIEGO, M., OR VILLAVERDE MENÉNDEZ, I.

6 Journal of Sessions No. 308 of April 24, 2013 available at: http://www.congreso.es/public_oficiales/L10/CONG/DS/CO/DSCD-10-CO-308.PDF pp. 2-4.
} 
CARBONELL (2006: 7) indicates that this protection is basic since this right reaches the most essential elements of the person. When the professor determines that the right of access to public information is intimately related to that of freedom of expression, with electoral rights and "more generally" with the democratic conception of the contemporary state, he is just pointing out basic elements of the person and the society, given that freedom of expression has no content without the information as well as suffrage cannot be properly exercised without the timely information to be able to exercise it if it is to be rational.

This reflection leads to consider the value of this right in a model of governance, so the right of access to information and the value of it in a democracy must be protected thoroughly if a real democracy is to be guaranteed and what better way to do it than with the deepening of the right of access. In this line of defense CARBONELL (2006: 10) makes a thesis from the antithesis when pointing out that in dictatorships and authoritarian regimes of despotic and populist type it has always been common to obstruct such a right. Thus exposed is what is diametrically opposed, a truly democratic government acts in a completely open way, that is, limiting secrecy to the maximum to allow free access to information and clearly that the best for such an aim is the consideration of this right as a fundamental one.

Another historic figure of this stage is MESTRE (1998: 71) although his ideas are not very far from those of POMED SÁNCHEZ. This author offers us a solid foundation of defense by connection in the fundamentalism of access when he speaks of the right of access to public information as the right to participate in public affairs where the right to access the administrative files and records is a necessary assumption for the exercise of the fundamental right contained in art. 23.1 CE "Citizens have the right to participate in public affairs ...". In particular, the singular Spanish case without an express or recognized fundamental constitutional right to public information, has also led to its indirect constitutionalization through the right to participate in the public affairs of art. 23 CE but with distorting effects. This is because only a fundamental right of public information is recognized for political representatives, but not for represented citizens. The consideration of the same right with a dual nature according to its exercise is, however, difficult to assimilate from a constitutional perspective, especially to act in both cases as a means for the exercise of fundamental rights and not as an end in itself.

The right of public information gives such coverage to human rights that are a further basis for sustaining the right of access as a fundamental right as it also opens a gap between its holders whose constitutionality can be challenged for having an objective and reasonable justification from the principle and right of equality. This is so since the reservation of public information with the rank of fundamental right is only for political representatives based on ius in officium, without citizens being guaranteed access to the same documentation. Here there is another small fundamentalist reason why the step must be taken.

Having said this, MESTRE (1998: 80) shows a certain fundamentalist reluctance in his interpretation of art. 105. b) CE when it is awarded to the media for journalistic 
purposes with which only they could have access to investigate records and archives to mediate and satisfy the formation of public opinion and the fundamental right to freely communicate with which the right of access remains in the range of instruments for this guild, the only subject of law of the precept. Although the link is exposed, this specific line of interpretation is not shared in this thesis or at this stage in the case that the fundamental right of access was only guaranteed by the journalistic sector as a conveyor of information, as this is reminiscent of censorship and repression.

The dependence of the right of access to public information with other fundamental goods as the right to expression is another foundation of fundamental importance. Thus, the fundamental right of art. $24.1 \mathrm{CE}$, for example, is not understandable for the author if it is not possible to access files that provide basic information to take a stand in a case, take action and act according to procedural law so that again the right of access would be an instrumental crutch of the right to judicial protection as well. MESTRE follows a similar connection with other primary rights as with the right to honor or to privacy, but not as an instrument but as a limit drawn from its literalness.

In this connectivity as a foundation, it could be argued again that of access with art. $20 \mathrm{CE}$. If something is to be expressed, that something quite possibly has been somewhere before rather than in possession of the person who expresses it. If a documentarist, an analyst, etc. possesses information about the public that they are going to present and express, it is because they have previously been nourished by that information and have needed access, this being a sine qua non requirement. In this line is DESANTES (1987: 160 and ss.), an author who argues that the legal foundations of the right to information of the fundamental art. $20 \mathrm{CE}$ connect with those who hold the art. 105. b) CE and that the recognition of the right of the latter is inadequately placed in the charter by not linking paragraph b) with a) or c).

The totally or partially iusfundamentalist authors pro fundamental right of access to public information also agree on interpreting the right of access from the freedom of information of art. $20 \mathrm{CE}$, which encompasses many rights such as research, broadcast and reception of information content, but there is no doubt, as stated, that to teach you have to learn how to inform, so you must be informed because knowledge is not authentic science. So if there is no right to be informed, the right to inform would be more an art than an exact science. For this reason they limit the right to be informed and to investigate to those who are professionally engaged in it.

Today this line is refutable alluding to the digital reality of a world in which TIC's turn the thumb into an information content broadcast channel so that each individual can broadcast information without having to dedicate themselves professionally to it and where the academic degree which certifies a profession according to research, is less and less required.

According to DESANTES's line of interpretation and to the digital fact of TIC, it should be noted that the current legislation has some failings in the application to the 
PTBG, since it provides the right to inform just to Spanish citizens who have an electronic ID and a card reader. Here we find a clear situation of informative discrimination or digital divide between those who have or do not have the possibility to acquire these mechanisms and to learn the knowledge necessary for their use.

Regarding that the state only releases information for the media and these are the only ones that broadcast it, an obvious assumption would be understood that much information would be left without being broadcast to free will of what the media considers necessary or not to do so in order to satisfy their duties and the popular interests. In addition, what information would be received if it is to be processed always by media always linked to opinions so that the quality and impartiality of the information would be battered? In our days fortunately the transparency of the administrations through their portals and other TICs make the state provide information to all interested citizens without going through the media.

With this new digital reality, it was not 10 years since the admired professor SÁNCHEZ DE DIEGO (2008: 32), said: "Recognition as a fundamental right (right of access to public information), if incardinated within the rights especially protected by the Spanish Constitution in articles 14 to 29, plus the objection of military conscience, will have a triple protection under article 53 of the Constitution: its development must be carried out by means of a Organic Law that respects its essential content; Its "amparo" before the ordinary courts by means of a procedure based on the principles of preference and summary and, as the case may be, through the "amparo" appeal before the Constitutional Court". This author, a member of this stage and inspiring for the writer, in his fierce defense of the iusfundamentalism of access which was based on the developed and consolidated structure in transparency, conscience, social demand and comparative law, later included reasons of digital access as another element of his defense.

As we see, access to public information is not only constitutionalized as a fundamental right by the general international influence, and specifically European, nor for reasons of comparative influence of the states but by the juridical osmosis with other human and constitutional rights. The instrumental and necessary cooperation of the public information in order to activate the right of participation, petition or the freedoms of opinion and expression, derives from the convergence in common legal goods, admitting that this constitutional provision expressly refers to the legal configuration of the exercise of the right of access to archives and administrative records.

Regarding the relationship between the right of access to information and other rights as a reinforcement of the fundamentalist reason for access, we also have the consideration of TORRES MANRIQUE (2013: 8), who adds that "the right of access to information in conjunction with other human rights contributes to its effective exercise, as stated by the Rapporteurship for Freedom of Expression within the scope of the Inter-American Commission on Human Rights in its Report of the year 2002". In these terms, it is pointed out that "the right of access to public information has acquired a fundamental importance in the development of Human Rights, directly linked to other 
fundamental rights, such as the right of access to justice, the right to the truth, the right to make informed citizen decisions and policies, democratic development and transparency in public administration".

Following the fundamental reasons for human rights and the access to information, another humanistic foundation must be touched upon, derived from art. 24 $\mathrm{CE}$, the right to the truth through access as the right of all persons arrested, convicted, prosecuted. If these persons, their "litisconsorts", guarantors, their technical defense and representation cannot access files with the guarantee that this is a fundamental right, legal security is restricted to the procedural capacity of the party that requires such access, access to the truth, so that the right to judicial protection and self-defense will be vulnerable. It is necessary to mention especially the development achieved by the right to the truth ${ }^{7}$, as a right that emanates from the International Law of Human Rights, and which nowadays acquires important attention, in direct and continuous relation with the access to public information. The development of the right of access to public information as a fundamental right and the recognition of the right to the truth now have solid foundations in international law and project significant legal consequences that contribute to the respect and full exercise of human rights and this has to be valued. ROMERO SILVERA (2010: 159 et seq.) maintains this foundation also, stating that "The lack of information or disinformation by the State is an element that characterizes human rights violations, State terrorism and, above all, the crime of enforced disappearance, which in turn constitutes a form of psychic torture for the relatives of the victims".

This dependence fully implicates the State from which the judicial branch is born, which supervises the information that makes it possible to clarify or prevent a violation of human rights, and which therefore can conceal, reserve, manipulate or destroy it, without the victims being able to exercise their legitimate rights in judicial proceedings. MENDEL (2010: note 10) points out that without a state that "allows access to information to victims of human rights violations, corrupt and inefficient governments cannot be denounced". In addition, it is the state that has the obligation to protect individuals within its jurisdiction in the use and enjoyment of their human rights, which makes it essential to have access to public information that allows victims to exercise their rights -"right to know or the right to the truth" on a plane of minimum equality-. ROMERO SILVERA (2010: 170) agrees that "in these cases the right of access to information transcends the scope that it has in itself and points to the instrumental or media dimension that is also attributed to it".

In short, the right to the truth and the right to access and receive public information are two aspects of the same obligation and both are based on the development of the stage of fundamental access. In this criterion the Inter-American Commission has been sensitive to affirm that "The whole society has the inalienable right to know the truth of what happened, as well as the reasons and circumstances in

${ }^{7}$ UN Commission on Human Rights, The Administration of Justice and Human Rights of Detainees, The question of impunity for perpetrators of human rights violations, Document. O.N.U. E / CN. 4 / Sub. 2/1997/20 / Rev. 1. 
which aberrant crimes came to be committed, in order to avoid that those facts happen again in the future". ${ }^{8}$

\section{THE RECENT DEFENSE OF THE RIGHT OF ACCESS TO PUBLIC INFORMATION}

The defense of the nature of a right of access as a fundamental right is made from two positions, the first one from the link to other fundamental rights existing in the Constitution, as we have developed in the previous section, and the second one by itself as an autonomous right. In this section we aim to consolidate positions, open new arguments and argue that our model allows the creation of fundamental rights without having to allude to the interpretation of other precepts. Many who deny the right of access to public information as a fundamental right base their position in the fact that the art. 10.2 CE does not allow the creation of new fundamental rights; it is true, but they can be interpreted, so in the position by connection the scope of art. $20 \mathrm{CE}$ regarding access can and should be interpreted, not to create a new right by connecting it with the citizen participation of art. 23 CE (although that too).

The first position that defends the fundamental nature of access can be said to be born of the inadequate and insufficient relation of access with art. 105. b) CE, which reduces the effectiveness that the LTBG would have had if it had be related to art. 20 CE. The art. 105.b) CE is located in the fourth title of the Constitution addressed to "Government and Administration"; however there are many more subjects involved the subjective scope of application of the art. 2 of the LTBG (Casa Real, foundations or mercantile companies with public participation). If we refer to the objective scope, art. 105. B) CE is still inappropriate since it focuses on "files and records" when the real object of the law is the "public information" that exists in many other places outside the files and records; indeed, the important thing is the content of the information no its continent.

On the other hand and in relation with the guarantees for the citizen, it must be mentioned that the art. 105. b) CE is outside the protection that art. $53 \mathrm{CE}$ offers in defense of the fundamental rights. So, it is evident that the power of protection would not have such outstanding jurisdiction as the constitutional one but, at first instance, that of administrative bodies such as the CTBG and, ultimately, the contentiousadministrative jurisdiction. If a legislative anchor is recognized in art. 20 CE it could be developed by an organic law (art. 81.1 CE) and would enjoy a constitutional guarantee for the "preference and summary" process mentioned in art. 53.2 CE.

The recognition of the fundamental nature of the topic further clarifies the position of the right of access to the levels of recognition enjoyed by other rights such as that of privacy. An added value that this development would have is the extension of its advantages to the questions of transparency and good governance giving meaning to

\footnotetext{
${ }^{8}$ OAS, IACHR, Annual Report of the Inter-American Commission on Human Rights 1985-1986, Chapter V, Available at: http://www.cidh.org/annualrep/85.86span/Indice.htm
} 
other norms that regulate these aspects along with access. This can be achieved through an organic law that develops a fundamental right.

In relation to comparative law, many reasons for influence have been studied and offered, from European states and international organizations, which push to locate the relation of the right of access in the right to information, according to art. 10.2 CE. I will mention that the International Covenant on Civil and Political Rights in its art. 19 refers to freedom of opinion and expression, however, the Human Rights Committee itself in 2011 clearly established that art. 19 sets out a right of access to information held by public bodies. It is again recognized there that under art. 13 of the International Covenant of San José de Costa Rica, freedom of expression protects the right of access to public information, since in order to have a free public opinion, it is necessary for citizens to have direct and unrestricted access to the information that is in the hands of the public authorities

Another suitable link, besides art. $20 \mathrm{CE}$, which allow the naturalization of access as fundamental right is art. 18.4 CE, a provision that determines the computer regulation in terms of honor, privacy and full exercise of rights -although the article, due to the context of the CE promulgation, does not regulate the right of access to the Internet or to computerized data-. An example is the Portuguese model, a precedent of rigorous regulation of the right of access through the constitution which in its art. 35 under the rubric "Use of information technology" reads:

"1. All citizens have the right to access computerized data concerning them, and may require their rectification and updating, as well as the right to know the purpose for which they are intended, in the terms established by law.

2. The law defines the concept of personal data as well as the conditions applicable to its automated processing, connection, transmission and use, and guarantees its protection, especially through an independent administrative entity ... ".

If the development of TICs and their generalization in society was a fact of transversality that served to develop a fundamental right that currently has great roots in citizenship, the same is true for openness and transparency. They are two elements that, as the digital age expands, are transversalized and reach all spheres.

In the second criterion of defense, the creation of fundamental rights is based on the fact that they are not numerus clausus; in fact in Spain some have already been created -for example, the right to the protection of personal data had an initial development to the LOPD in the famous 1992 organic law regulating the automatic processing of personal data. The same jurisdictional authority in the constitutional order has developed other fundamental rights such as the right to the creation of means of communication and to exercise the "right to manage and exploit information" (in particular STC 12/1982 of $31 \mathrm{March}^{9}$ ).

\footnotetext{
${ }^{9}$ BOE num. 95, of 21 April 1982 available at: http://hj.tribunalconstitucional.es/es/Resolucion/Show/54
} 
Entering into criteria, if a fundamental right is considered as such is to the extent that it can provide measures of integral protection of the person, according to CARBONELL (2006: 4), the preservation of basic goods necessary to be able to develop a dignified life. The author agrees with this reasoning, as contrasted with the current model of dignified life, that it is unimaginable the dignity of opacity, parsimony and absence of administrative light. The attack on the fundamental right of access from the beginning is very interesting since it is as simple and complex as the study the theory of fundamental rights and line by line contrasts its extrapolation to the right of access to information from which he turns out that all the premises can be adjusted. CARBONELL (2006: 4) wrote that "when we talk about fundamental rights we are talking about protecting the most vital interests of all people, regardless of their personal tastes, their preferences or any other circumstance that may characterize their existence. That is why it can be said that fundamental rights must be universal because they protect goods with which every person must contact, regardless of where they are born, their income level or their physical characteristics".

\section{CONCLUSION}

The Law 19/2013 seeks to fill a legal void that existed. However in practice it is a text which should be improved because it fails to categorize the right to public information within the fundamental rights nor does it reach the international standards set by numerous international courts and declarations, a conclusion based on the study of comparative law. In view of the above, it can be affirmed first and foremost that in our country there is a doctrinal interest in the field of access to public information resulting from the mainstreaming of this right in all fields of law.

We can see that it also strengthens the ground that the constitutional right of access to information as instrumental and it is considered to be part of the additional content of the fundamental right to receive truthful information by any means of dissemination contemplated in art. 20.1.d) CE, since it is configured as a variant modality in the receipt of specific information, constituting the public administration as the source of dissemination of information of general interest.

The existing dispute in the interpretation about the nature of the right of access to public information is referred and revolves around two main lines: that of linking the right of access to an already existing fundamental right or positioning it as a fundamental right autonomous and independent of new creation. There are authors who in this regard find this possible, supported by international influence and other authors who rely on constitutional rules to close the list of rights to those already enumerated. Two new approaches are offered that should be considered in the near future to reform the constitution and strengthen the status of the citizen and resemble the countries in the environment in which we live, in addition to complying with international premises. 


\section{REFERENCES}

ALEXY, R. (1993). Teoría de los derechos fundamentales, Madrid: Centro de Estudios Constitucionales.

ÁLVAREZ RICO, M. (1979). "El derecho de acceso a los documentos administrativos”, Documentación Administrativa, N. 183.

CARBONELL SÁNCHEZ, M. (2006). "El derecho de acceso a la información como derecho fundamental”, in Democracia, transparencia y Constitución: propuestas para un debate necesario, México: UNAM.

COTINO HUESO, L. (2005). "El nuevo derecho fundamental europeo al acceso a los documentos, transparencia e información pública”, in Homenaje a D. Íñigo Cavero Lataillade, Valencia: Tirant lo Blanch, pp. 725-753.

DESANTES GUANTER, J. (1987). Teoría y régimen jurídico de la documentación, Madrid: Eudema.

EMBID IRUJO, A. (1994). El ciudadano y la Administración, Madrid: Instituto Nacional de la Administración Pública.

FERNÁNDEZ RAMOS, S. (1997). El derecho de acceso a los documentos administrativos, Madrid: Marcial Pons.

GUICHOT REINA, E. (2003). "El nuevo derecho Europeo de acceso a la información pública”, Revista de Administración Pública, Centro de Estudios Políticos y Constitucionales de Madrid, N. 160.

GUICHOT REINA, E. (2011). “Transparencia y acceso a la información pública en España: análisis y propuestas legislativas. Documentos de trabajo”, Laboratorio de alternativas, N. 170, 2011. Work paper 170.

MENDEL, T. (2003). "Libertad de información: derecho humano protegido internacionalmente”, Derecho Comparado de la Información, N.. 1.

MESTRE DELGADO, J. (1998). El derecho de acceso a los Archivos y Registros administrativos. Análisis del artículo 105.b) de la Constitución, Madrid: Civitas.

POMED SÁNCHEZ, L. (1989). El derecho de acceso de los ciudadanos a los archivos y registros administrativos, Madrid: INAP.

RIDAO MARTÍN, J. (2014). "La regulación de la transparencia y del acceso a la información pública en la esfera autonómica. Un estudio comparado”, Revista General Derecho Constitucional, N. 19.

ROMERO SILVERA, G. (2010). “Implicaciones jurídicas del desarrollo del derecho de acceso a la información pública en el marco del derecho a la libertad de expresión y los derechos humanos”, American University International Law Review, $26 \mathrm{nN} .1$. 
RUIZ RUIZ, R., DEL REAL ALCALÁ, A., ANSUÁTEGUI ROIG, F., LÓPEZ GARCÍA, J. (2005). Derechos fundamentales, valores y multiculturalismo, Madrid: Dykinson.

RUIZ-RICO RUIZ, C. (2014). "Breves consideraciones jurídicas en torno a la reciente Ley 19/2013, 9 de diciembre, de Transparencia, Acceso a la Información Pública y Buen Gobierno", Boletín Mexicano de Derecho Comparado, N. 140.

SÁNCHEZ DE DIEGO FERNÁNDEZ DE LA RIVA, M. (2008). Un derecho fundamental a acceder a la información pública, El derecho de acceso a la información pública, Actas del Seminario Internacional Complutense, Madrid: Facultad de Ciencias de la Información, Universidad Complutense de Madrid.

TORRES MANRIQUE, F. (2013). Una mirada crítica a los derechos a la transparencia, información pública y rendición de cuentas, Lima: Derecho y Cambio Social.

VILLAVERDE MENÉNDEZ, I. (1993). "Derecho a ser informado y el artículo 20.1 de la Constitución Española, Estudios de Derecho Público”, in Homenaje a Ignacio de Otto, Oviedo: Universidad de Oviedo, pp. 545-581. 